\title{
Heritage Conservation in Postcolonial India
}

\author{
Pilar M. Guerrieri*
}

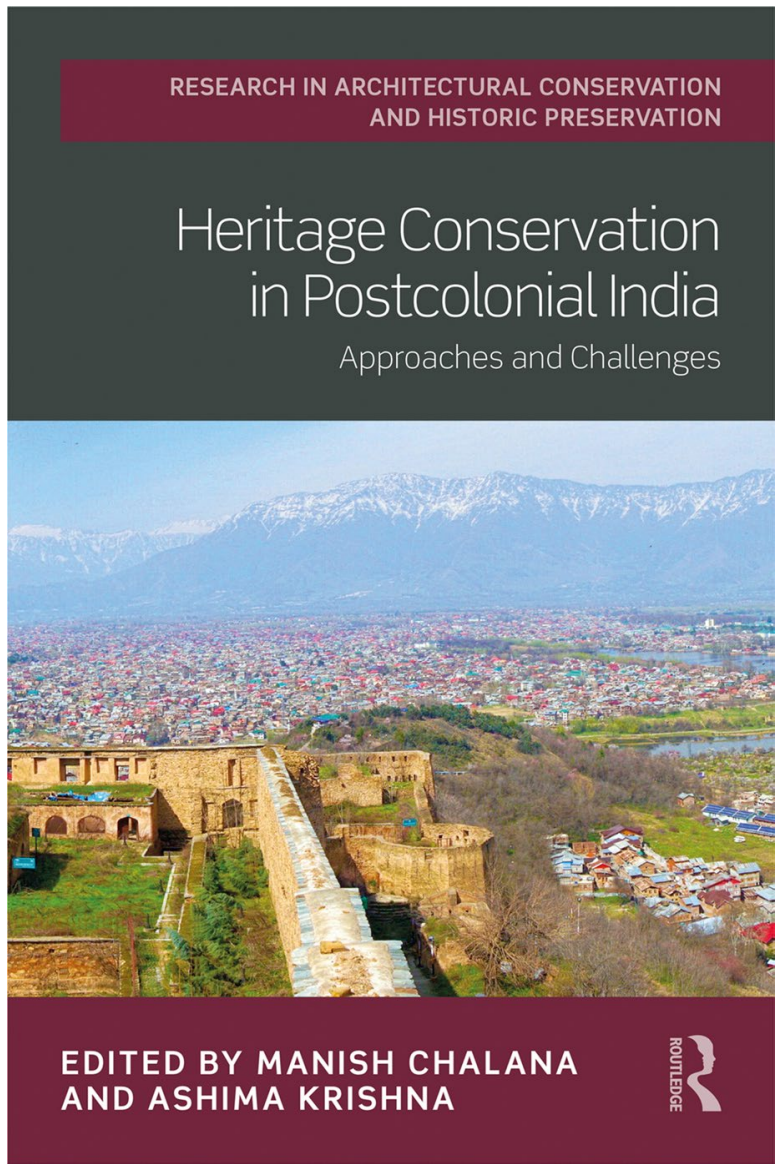

Heritage Conservation in Postcolonial India. Approaches and Challenges, edited by Manish Chalana and Ashima Krishna, is very rich, and counts thirteenth different contributors among urban and architectural

*Correspondence: pilar.guerrieri@polimi.it

Department DASTU, Politecnico Di Milano, Edoardo Bonardi, 3 20133, 20133 Milano, MI, Italy conservationists, urban and historic preservation planners, landscape designers and architects, social entrepreneurs, experts in cultural heritage from universities, social and research institutions.

The book acknowledges that most texts in the field of conservation and heritage in India are predominantly Western focused, and that practices of conservation have been largely legacy of colonial powers and influenced by the international doctrine of conservation. Interestingly, this volume seeks to present a more 'Indian' approach and perspective on the matter of conservation.

The introductory chapter provides an overview of the historical development of the formal profession of heritage conservation in India, since the creation of the socalled Archaeological Survey of India (ASI), established under the British Raj in the second half of the 19th century. Its creation in 1861 marks the formal birth of the profession of heritage conservation in India, with the task of documenting and protecting India's antiquity by conducting geographical surveys of historic and archaeological sites. The agency produced a landmark handbook of best practices in 1923, which provided technical instructions on building conservation with the goal of ensuring uniformity of the conservation practice across the empire. The agency kept meticulous annual records, publishing reports on various excavations and on artefacts associated with specific excavations. After independence, ASI continued to dominate the formal practice of heritage conservation. The agency currently protects over 3,677 monuments and archaeological sites.

One of the most relevant points that the book makes is that the field of heritage conservation in India has interestingly expanded beyond the ASI in recent decades. An important step was the creation of the Indian National Trust for Art and Cultural Heritage (INTACH) in 1984. INTACH is a parallel non-governmental preservation organisation focusing on advocacy, education and
Springer Open (c) The Author(s) 2022. Open Access This article is licensed under a Creative Commons Attribution 4.0 International License, which permits use, sharing, adaptation, distribution and reproduction in any medium or format, as long as you give appropriate credit to the original author(s) and the source, provide a link to the Creative Commons licence, and indicate if changes were made. The images or other third party material in this article are included in the article's Creative Commons licence, unless indicated otherwise in a credit line to the material. If material is not included in the article's Creative Commons licence and your intended use is not permitted by statutory regulation or exceeds the permitted use, you will need to obtain permission directly from the copyright holder. To view a copy of this licence, visit http://creativecommons.org/licenses/by/4.0/. 
outreach on matters of heritage conservation, producing an extensive repository of in-house publications covering case studies of both tangible and intangible heritage. INTACH published a compendium of good practices for urban heritage in India and a technical manual called Guidelines for the Preparation of a Heritage Management Plan. One of the most significant contributions of INTACH has been its effort to dramatically expand the ASI listing and documentation of built, natural, cultural and intangible heritage relative.

The book is split in four main sections covering themes such as: institutional and programmatic developments in the field of conservation, critical and contemporary challenges facing the profession, emerging trends in practice that seek to address contemporary challenges, and sustainable solutions to conservation issues.

The first section comprises chapters that discuss how institutions and programs in India have evolved since independence, and how heritage conservation was professionalised. This section provides an introductory framework presenting the historical role of ASI in Chapter 1, The evolving role of India's foremost heritage custodian: The Archaeological Survey of India, by Saptarshi Sanyal; and the role of INTACH in Chapter 2, The role of Indian National trust for Art and Cultural Heritage in heritage conservation in India, by Divay Gupta. Chapter 3, Heritage management and conservation planning for historic cities in India: The case of Jaipur and Ajmer, by Shikha Jain, discusses how conservation planning of historic cities is fundamental for a more effective urban development. Ashima Krishna's Chapter 4, Tools for heritage advocacy in Lucknow: Active civic engagement and public interest litigation, explains how cities without local heritage policies can achieve successful conservation outcomes through citizen advocacy and activism. Chapter 5 , Heritage education: An essential element in elementary education, by Michael A. Tomlan, address programmes that promote heritage conservation among children through primary education.

The second section highlights various practice-oriented challenges faced by the field of conservation today. Chapter 6, History, memory and contestation: Challenges in preserving Amritsar's diverse heritage, by Gurmeet S. Rai and Churnjeet Manh; examines the decade long struggle to conserve the Maharaja Ranjit Singh's palace in Amritsar. Swapna Kothari in Chapter 7, Loss of cultural artefacts: Continuing challenges around antiquities trafficking from India, investigates specifically issues related to the illicit trade of Indian art and artefacts. Priya Jain's Chapter 8, India's modern heritage: conservation challenges and opportunities, focuses on an aspect of heritage conservation often neglected in India, such as modern architecture. Chapter 9, Heritage conservation and seismic mitigation in small-town in India: The case of Chamba, Himachal Pradesh, by Manish Chalana and Sakriti Vishwakarma, looks at the small town of Chamba to highlight how vernacular architecture and cultural landscape are often left ignored.

The section three of the volume focuses on the emerging trends in the field of heritage conservation, such as challenges in maintaining the vernacular-built environments or traditional craft knowledge systems. In Chapter 10, Making heritage accessible to all: Experiments with digital technologies for urban heritage conservation in India, Aishwarya Tipnis showcases her work, devising sustainable solutions integrating digital technologies with heritage conservation. Kamalika Bose in Chapter 11, Reclaiming neighbourhood, rebonding community: Urban conservation initiatives for Kolkata Chinatown, details issues in conserving the threatened urban heritage of Kolkata Chinatown. Patricia Tusa Fels in Chapter 12, Saving the history of Malabar mosques and their communities, discusses the vernacular mosques in Kerala and the challenges faced by conservation practice in the region. In Chapter 13, Craft as intangible heritage: The Thatheras of Jandiala Guru, Punjab, Yaaminey Mubayi highlights the uniqueness of the craft metalsmithing manufacturing process in Punjab.

The fourth section takes the heritage conservation forward through discussions of sustainable approaches to heritage conservation projects, i.e., encouraging the relationship between human and nature, and promoting integrated sustainable tourism. Amita Sinha's Chapter 14, Ghats on the Ganga in Varanasi: A sustainable approach to landscape conservation examines the complex landscape of ghats, discussing sustainable approaches to resolving contemporary issues in Varanasi. In Chapter 15, Conservation of Indo-Islamicate water experience, James L. Wescoat JR. examines historical approaches to water based Islamicate designs in northern and western India. Priyaleen Singh's Chapter 16, Restoring nurturing the 'nature-human' bond through conservation of historic gardens, explores the relationship between humans and nature through the survey of historic gardens, whereas Ananya Bhattacharya's Chapter 17, Community led sustainable cultural tourism, focuses on environmental approaches to conservation of intangible heritage in West Bengal in their original context. Finally, Manish Chalana and Ashima Krishna conclude with the chapter titled Past forward: preparing heritage conservation in India for the twenty-first century presenting some of the interesting continuing challenges in the field of heritage conservation in India.

As it might appear evident, the topics covered in the four sections are very heterogeneous, they give a very broad understanding of the complexity and variety of the 
existent conservation issues. The book is very thoughtprovoking because it highlights a multi-faced and diverse approach to heritage conservation in India, overcoming the ASI's monument-centric attitude, including vernacular, rural and intangible heritage in the picture, and introducing the question of how heritage conservation can be integrated into planning and development initiatives and policy.

The book has the merit of focusing on the plethora of Indian unprotected heritage, many sites that represent part of Indian living heritage, all those that often remain vulnerable to insensitive modernisation, urbanisation and uncontrolled development.

The book showcases different ways of conservation and urban renewal, and the implementation of a variety of urban-heritage projects in Indian cities, where protection is not solely confined to valuable single monuments, but it comprises large portions of cities and towns, such as Jaipur, Ajmer or Lucknow.

The manuscript emphasises the importance of regulating the antiquity artefacts in the subcontinent, as an integral part of the important commitment to Indian heritage conservation. The authors are keen to recognise the cultural value of crafts, highlighting their significance as living heritage of India, and their importance for people's livelihood. This constitutes a valuable soft heritage in the context of India. The book also emphasises the importance of maintaining a relationship between the community and the monuments in order to really achieve heritage conservation. In one of the chapter the very important, often neglected, topic of conservation of Indian modern heritage is discussed as part of the overall heritage conservation matter. The book tries to overcome the prevailing monument-centric attitude, highlighting the value of vernacular cultural resources and cultural landscapes in place-making, and in responding to natural hazards. The authors propose the idea of nature as heritage that needs to be preserved, such as water bodies, historic gardens and elements. Natural threats and climate change are taken into account as undeniable new challenges for the professionals in the field of conservation. A major task for heritage conservation revolves around equity and social justice, and some authors suggest the possible inclusion of new digital technologies to make heritage accessible to all. The book highlights possibilities of engaging schools in improving heritage activities, explaining the importance of working with the educators in existing schools, developing partnership with heritage organisations and museums. Educating skilled and sensitive conservation professionals, fully equipped to meet the changing context, values and needs is described as necessary.
There are interesting articles, and fewer books, on methodologies of architectural conservation in India, among these: The Conservation of Indian Heritage (1989) by B. Allchin, F.R. Allchin and B.K. Thapar, a collection of articles by different authors, Heritage Conservation Preservation and Restoration of Monuments by N.L. Batra (1996). Other books are on museums and conservation of other forms of art or historical records, such as Conservation and Restoration of Cultural Heritage by Arun Ghose (1989). What is suggested in Heritage Conservation in Postcolonial India widens the horizon of Indian heritage conservation, shading light on traditional practices but also highlighting India's innovative perspectives and points of view. This is an endeavour that is surely unique compared to previous existing books. This book is interesting for many different kinds of professionals, and surely stands as a fundamental cornerstone for further analysis on the topic.

\section{Acknowledgements}

Not applicable.

\section{Authors' contributions}

All author(s) read and approved the final manuscript.

Funding

Not applicable

Availability of data and materials

Not applicable

\section{Declarations}

Competing interests

The author declare that they have no competing interests.

Received: 23 January 2022 Accepted: 3 February 2022

Published online: 07 March 2022

\section{References}

Allchin, B., F.R. Allchin, and B.K. Thapar. 1989. The Conservation of Indian Heritage. New Delhi: Cosmo Publications.

Batra, N.L. 1996. Heritage Conservation Preservation and Restoration of Monuments. New Delhi: Aryan Books International.

Ghose, A. 1989. Conservation and Restoration of Cultural Heritage. Delhi: Agam Kala Prakashan.

\section{Publisher's Note}

Springer Nature remains neutral with regard to jurisdictional claims in published maps and institutional affiliations. 